\title{
Accounting
}

\section{Profitability and value of firm: An evidence from manufacturing industry in Indonesia}

\author{
Siwi Aryantini ${ }^{a^{*}}$ and Sapto Jumono ${ }^{a}$
}

${ }^{a}$ Esa Unggul University, Indonesia

C H R O N I C L E

\section{Article history:}

Received: November 28, 2020

Received in revised format:

December 282020

Accepted: February 7, 2021

Available online:

February 7, 2021

Keywords:

DuPont Analysis

Growth Sales Ratio

Profitability

Types of Industry

Value of Firm

\begin{abstract}
A B S T R A C T
The purposes of this research were to understand the profitability performance and its influencing factors based on DuPont Analysis and the effect toward the value of the firm. As a causality research, the sample data involved were 20 non-banking and finance companies as listed on LQ-45 of Indonesian Stock Exchange (IDX) years of 2014-2018, which could be classified into two types of industry; manufacture and non-manufacture sectors. The research's quantitative design as a systematic approach of the relation among the variables focusing on the hypothesis testing done by data analysis tools using GLS Regression test of panel data. Profitability determinants of net profit margin, total assets turnover and financial leverage multiplier showed the result of positive and significant effect toward ROE (return on equity), while growth sales ratio showed the negative and significant effect. In terms of the relationship toward value of firm, the ROE and industry types were proven to have significant positive contributions. This implied that the management must be more efficient and effective in managing the company operational activities and minimizing the operational costs and other costs, both in the assets and debt usage to have maximal product results, to increase sales, net income, profit rate and return of equity where they will affect the increasing of investors' and the market's trust toward the firms since the increasing of return on equity for the owners and the shareholders. The different characteristics, traits and features of the industry's types resulted in the different use of strategies in managing the firms' operational activities. These all affected the increasing value of the firm.
\end{abstract}

\section{Introduction}

Increasing the value of firm for the go-public firms is very essential since it's closely related to the owner or the shareholders prosperity beside it also shows the firm's performance which can affect the shareholders perception about the success rate of a firm that is often associated with the stock price (Brigham \& Houston, 2009). The high value of the firm will make the market trust the prospect in the future. The most popular tool to measure the performance is the Return on Equity (ROE). DuPont analysis as one of the tools to analyze the profit of a firm or a business has one fundamental indicator that is the ROE which focusing in three essential components in the firm's finance position, they are the operational management, the assets management and the capital structure as stated by Gleim \& Flesher (2015) in Warrad \& Nassar (2017) that the DuPont Formula showing the relation between the main finance ratio of Net Profit Margin, Total Asset Turnover and Financial Leverage Multiplier. 
Some previous studies have been done such as one by Warrad \& Nassar (2017) stating that there is significant effect from the total assets turnover and net profit margin in ROE DuPont Model, and there is no significant effect from leverage financing in ROE DuPont Model. On the other hand, there is significant effect from total asset turnover, net profit margin and leverage cofinancing in ROE DuPont Model. From the research objects taken, Kijewska (2016) did a research for DuPont formula variables with three indicators as the main determinants, they were net profit margin, assets turnover and equity multiplier, stating that the trend of ROE is decreasing, with the main factor contributing in it is the net profit margin indicator. Meanwhile, Raza (2017) stated that the profit margin and total asset turnover have positive impact on return on equity, and the equity multiplier does not have a positive impact on return on equity. Weidman et al. (2019) found that the most important determinant of ROE is the net profit margin in manufacturing firms as researched in the three countries; USA, Germany and Japan. Meanwhile, research by Ahmad et al., (2015) showed that the results of financial leverage have a statistically significant inverse impact on profitability. Cowling's (2004) showed that growth and profits moved in parallel. Growth Sales Ratio (GSR) or the sales growth is often used as a benchmark in assessing the development of a firm. Sales are the spearhead of a firm. The high sales growth ratio means that the firm's activities are increasing. Sales must cover the costs to increase profits. Sucuahi \& Cambarihan (2016) in their research on some firms in the Philippines showed that profitability had a positive and significant impact on firm's value.

However, this research used a different object from the sample of Non-Banking and Financial firms which are included in the LQ-45 list on the IDX for the period of 2014-2018 and were classified into types of manufacturing and non-manufacturing industries, as well as different research methods compared to the previous studies. This research used panel data regression from the results of the GLS Regression Test with previous tests including Chow Test, Lagrangian Multiplier Test, Hausman Test and Blue Test. Seeing the previous research with different data samples used, this research aims to understand the profitability performance and its influencing factors based on DuPont Analysis and the effect toward value of firms.

\section{Literature Review and Hypothesis Development}

\subsection{DuPont Analysis}

In 1920, the DuPont Analysis methods was developed as firstly stated by DuPont Corporation, then turned into a tool to analyze the profit both for the firm and business as the financial ratio to measure the firm's ability to increase the Return on Equity (ROE). As stated in Brigham \& Houston (2009), it is explained that the DuPont approach as a general approach shows that ROE is affected by the profit margin, total assets turnover, and leverage indicators. Net Profit Margin (NPM) as the profit margin indicator as mentioned in Brigham \& Houston (2009) is the ratio of net income to net sales of the firm to measure the firm's ability to generate net income obtained with each value of sales generated. Total Assets Turn Over (TATO) indicator as the activity ratio comparing between the sales rate and investment in all kinds of used assets to measure the effectiveness of the firm's asset resources (Brigham \& Houston, 2009). The higher the assets turnover means the more effective the use of firm's assets resources to increase the sales, and it will affect the increasing of profit gained, with a note that the other factors are assumed to be constant. While Financial Leverage Multiplier (FLM) as the leverage indicator explaining the value of total assets compared to the firm' equity value. This can also be assumed as the amount of debt used on the total assets owned by the firm as stated in (Singapurwoko \& El-Wahid, 2011). Return on Equity (ROE) which is the basic fundamental indicator in Dupont Analysis can be described as the DuPont Formula in the figure below:

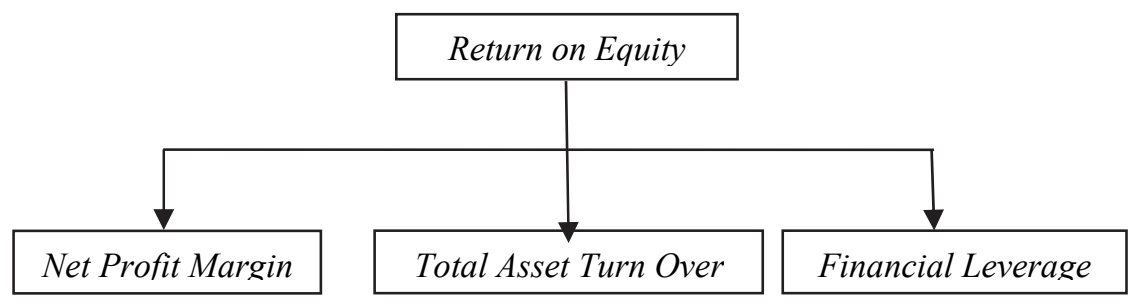

Fig. 1. Main Components of DuPont ROE

The DuPont equation shows the ROE Formula as DuPont ROE Formula written below:

$$
\begin{aligned}
\mathrm{ROE} & =(\text { Profit margin }) \times(\text { Total Assets Turnover }) \times(\text { Equity Multiplier }) \\
& =\frac{\text { Net profit }}{\text { Sales }} \times \frac{\text { Sales }}{\text { Total Assets }} \times \frac{\text { Total Asets }}{\text { Common Stock Equity }}
\end{aligned}
$$




\subsection{Return on Equity}

The ROE ratio is a measure of the return rate obtained by the firms' rate on shareholders' equity. The ROE calculation can show how effective the firm's management in using the investors' money. ROE can show whether a management can grow the value of the firm at an acceptable level. As the profitability ratio that becomes the calculation direction of DuPont Analysis, ROE is the benchmark of a firm's financial performance measured by the net profit on equity. The increased ROE ratio shows a signal that the firm is able to generate profits without adding new equity into the business enterprise, or as a condition where the profit from the shares' ownership is distributed to the shareholders (Kijewska, 2016).

\subsection{Trade-off Theory}

The application of Trade-off Theory focusing on the cost analysis and debt benefit predicting that there is an optimal debt ratio that helps maximizing the value of firm, as stated by Myers (2001), to seek the balance point between the debt level and tax advantages from the additional debts.

\subsection{Price Earnings Ratio}

To assess a firm, the Price Earnings Ratio (PER) is often used as one of indicator approaches. If the firm's assets are sold according to the ratio between the market price per share divided by EPS so the actual value per share will be accepted as the value of the firm, as stated by (Gitman \& Zutter, 2015). Or it can also be stated as the profit gained by the investor or the shareholders per share. The higher the stock price, the higher the return rate to the investors means the better prosperity of the shareholders and the higher the value of the firm will be (Brigham \& Houston, 2009).

\subsection{Value of the Firm}

Value of the Firm as mentioned by Brigham \& Houston (2019) stating that the main purpose of the go-public firms is to maximize value for the long term by maximizing the shareholders' prosperity . It includes a high assessment from the external about the firm's assets and the growth of the stock market.

\subsection{Growth Sales Ratio}

Growth Sales Ratio (GSR) as the growth indicator is the result of a comparison between the difference in sales for the current year and sales in the previous year with sales in the previous year. According to Barton, et al. (1989), growth of sales reflects the manifestation of past periods of investment success and can serve as predictions of future growth. The greater the rate of sales growth, the greater the resulting profit. This has an impact on the investors' interests to invest in the firms which also affects the increase in stock prices, as well as increasing the value of the firm (Van Horne \& Wachowicz Jr., 2008). Those conditions will grow the investors' interest to invest their capital to the firms then it will affect the stock price and the value of the firm to increase.

\subsection{Types of Industry}

Referring to the industrial classification as defined by Indonesian Stock Exchange (IDX) called JASICA (Jakarta Stock Exchange Industrial Classification), industries can be categorized into namely the producer of raw materials industry sector, the manufacturing industry sector and the service industry sector. In this research, industry will be classified into manufacturing industry and non-manufacturing industry.

\subsection{Hypotheses}

\subsubsection{The Relationship between Net Profit Margin (NPM) and Return on Equity}

The higher the Net Profit Margin value and the more efficient cost usage means the higher profit returns as mentioned by Robert Ang (2010) in (Karimah, 2018). The high profit gained by the firm will greatly affect the value of ROE, where the higher the profit gained the more ROE gained. Weidman et al. (2019) found that the most important determinant from ROE is the NPM, based on the research done in three countries: the USA, Germany and Japan. Previous empirical evidence from Raza (2017) 
shows that the profit margin and total asset turnover have a positive impact on the return on equity. The efficient and effective use of assets increases profit margins from an increase in sales, thus resulting in an increase in the rate of return on profits obtained. Likewise, Warrad \& Nassar (2017) also find a positive relationship between NPM and ROE. Based on the description above, the following hypothesis is proposed:

\section{H1: There is a positive effect from Net Profit Margin to Return on Equity.}

\subsubsection{The Relation between Total Assets Turn Over and Return on Equity}

The higher the total assets turn over will be because it means the more effective and efficient in terms of assets resources usage or all assets in the firm to support the operational activity in increasing the sales, so it will influence the higher profit that will be gained. Bunea et al. (2019) states that the strongest influence of ROE is the assets turnover ratio, with positive impact. Alarussi \& Alhaderi (2018) show a strong positive relationship between total sales, working capital, assets turnover ratio toward profitability. It is also stated by (Warrad \& Nassar, 2017) who find that there is significant effect from the total assets turnover in DuPont ROE model. In the contrary, Circiumaru et al. (2010) concluded that only net operating margin is correlated with ROE, while the total asset turnover and leverage didn't validate a linier correlation. So were the conclusion by Rahmah. Et.al (2016) and Jumahana (2017) in (Irman \& Purwati, 2020), stated that total assets turnover had a significant negative impact toward profitability. Based on the description above, the following hypothesis is proposed:

\section{H2: There is a positive effect from Total Assets Turn Over toward Return to Equity.}

\subsubsection{The Relation between Financial Leverage Multiplier and Return on Equity}

The debts can reduce the tax. That's why a firm with high profitability will try to reduce tax by increasing the debts ratio. It is consistent with the Trade-Off theory which states that the firm tries to seek the debt rate that would balance out the tax advantage from the additional debts toward financial difficulty costs. In reality, the financial managers rarely think that way. Ahmad et al. (2015) showed that financial leverage has a significant negative correlation to the firm profitability. Saleem \& Rehman (2012) in Raza (2017) found that oil and gas firms with high leverage generally have lower profitability. The firms with high leverage are riskier in terms of investment which also causes more risks for ROE. This is parallel with the research results (Alarussi \& Alhaderi, 2018; Warrad \& Nassar, 2017) showing the negative relation between leverage and profitability and contrary to the Trade-off theory. Based on the argument above and with the reference of the Trade-off theory, the following hypothesis is proposed:

\section{$\mathbf{H}_{3}$ : There is a positive effect from Finance Leverage Multiplier to Return on Equity.}

\subsubsection{The Relation between Growth Sales Ratio and Return on Equity}

The development of a firm also can be seen from the condition of sales growth or Growth Sales Ratio (GSR) as a measure of the assessment, beside it can also be seen from the product sales trends from year to year. The firms' activities are said to be increasing with the high growth sales ratio. The firms' profit can increase if the income as the results of sales can cover the costs spent, so the profit gained and the shares demand increase then affecting the stock price rising so that the firms can earn the return. This is consistent with the results of Cowling (2004) study showing that growth and profits move in parallel. On the other hand, Sivathaasan et al. (2013) found that the growth rate had an insignificant negative impact on profitability. Referring to the empirical data above, the hypothesis is made as follows:

\section{H4: There is a positive impact from Growth Sales Ratio to Return on Equity.}

\subsubsection{The Relation between Return on Equity and Price Earnings Ratio}

The effectiveness rate of a firm's management in making the profit can be seen and measured from the ROE value as the profitability ratio. The high ROE ratio means the firm is also making high profit. It reflects that the firm has a good prospect in the future, where it is desired by the investors to have bigger interest for buying the shares. The higher demands from investors for shares will affect the stock price and increase the value of the firm. It can be said that the higher the firm's profitability, the higher the value of the firm will be. Sucuahi \& Cambarihan (2016) revealed that among the three factors called type of industry, the age of the firm and the profitability which assumed to affect the value of the firm, only profitability showed the positive impact and significantly on the value of the firm. Based on the description above, the following hypothesis is proposed: 


\subsubsection{The Relation of Industry Types on Return on Equity and Price Earnings Ratio}

The manufacturing industry sector as one of the most complete sectors in its industrial activities compared to the other two sectors, namely the raw material-producing industrial sector and the service industry sector, which includes managing activities from raw materials to finished goods and then selling them to consumers, involving the making of products through various processes, machines and operations, following a well-organized plan for each required activity. Manufacturing usually means mass production to sell to customers for a profit. Goddard et al. (2005) proved the relationship between the size and the profitability was negative, but the relations between market share and profitability was positive, and the results were stronger in manufacturing firms than in service firms. Pervan et al. (2019) revealed that firm age, labour costs and industry concentration, as well as the GDP growth and inflation had a significant effect on the profitability of manufacturing firms. Winarto (2015) revealed that liquidity had a negative and significant effect on the value of manufacturing firms. On the other hand, financing policies, dividends, and profitability had a positive and significant impact on the firm value. A research by Lestari \& Armayah (2016) was conducted on manufacturing firms showing the outcome where Return on Investment and Return on Equity has a positive and significant effect on the value of the firm. Mursalim et al. (2015) also conducted research on manufacturing firms showing that investment decision, the capital structure, dividend policy, and innovation affecting the firm profitability positively and significantly. On the other hand, investment decisions, capital structure, and innovation also affect the value of the firm positively and significantly, while dividend policy did not affect the value of the firm, while profitability affected it positively and significantly. Based on the description above, the following hypothesis are taken:

\section{H6: There is a positive effect from the manufacturing-type industry to Return on Equity.}

H7: There is a positive effect from the manufacture-type industry to Price Earnings Ratio.

Based on the hypotheses above, the research model can be described as follows:

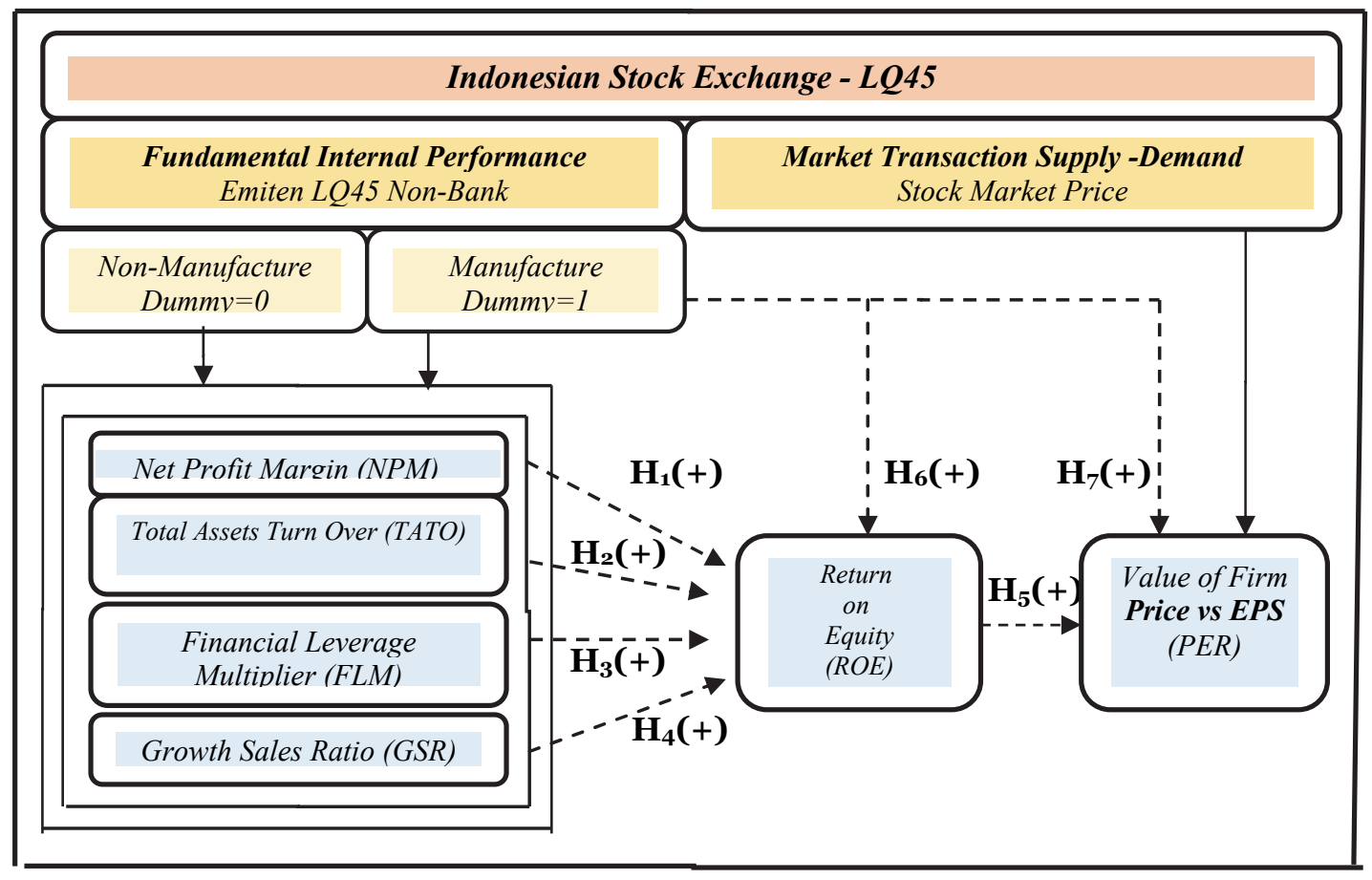

Fig. 2. Research Model

\section{Research method}

This is a causality research with panel data using secondary data where the data sample were taken by Purposive Sampling and Time Series with the criteria are; the firm is a Non-Banking and Finance firm as listed in LQ-45 in Indonesia 
Stock Exchange, publishes financial annual Report with the period of 2014 to 2018, and has been audited by an independent public accounting firm and published in www.idx.co.id. As for the industry types variables are classified into two categories: industrial sectors of manufacturing and non-manufacturing, referred to a classification of industries set by BEI called JASICA (Jakarta Stock Exchange Industrial Classification) dividing into three industry types; the raw-producing materials sector, the manufacturing sector and the service sector. The measurement of the industry type variable using a dummy number, where the number 1 is for the manufacturing industry sector and the number 0 is for the non-manufacturing industrial sector. The number of secondary data as the research objects involved in this research is 20 firms with various backgrounds, consisting of 9 manufacturing firms and 11 non-manufacturing firms. The research design was done quantitatively because it required a systematic approach to the relation between variables focusing on hypothesis testing. The tests were performed using statistical tools called StataCorp Stata 14.2 Software. This research is also an integrated general approach to financial ratio analysis showing how return on equity is affected by profit margins, asset turnover, leverage, sales growth and type of industry. There is also the general approach showing how the return on equity and types of industry affects the value of the firm. The hypotheses were tested using GLS Regression test of panel data to determine whether the structure has a significant relation or not. The regression analysis data used was the data that has been selected from one of the three models called Common Effect Model / Ordinary Least Square, Fixed Effect Model and Random Effect Model. Then they proceeded with the Blue Test (Multicollinearity, Heteroscedasticity and Autocorrelation). If in the Blue Test the best model still had problems with multicollinearity, heteroscedasticity and autocorrelation, then the Robust Test was carried out to provide the Output Test which is used to correct the classical assumptions. This was done if the selected estimation model was Ordinary Least Square and Fixed Effect. However, if the Random Effect model was chosen, it didn't need to be tested again because the GLSRegression had been processed in the previous test stage. The panel data regression equation as the output of the selected model can be used as the data for interpretation of the regression results (Suwardi, 2011).

Table 1

Operational Variables

\begin{tabular}{|c|c|c|c|}
\hline Variable & Operational Definition & Proxy & $\begin{array}{c}\text { Measure } \\
\text { Scale }\end{array}$ \\
\hline $\begin{array}{l}\text { Net Profit } \\
\text { Margin (NPM) }\end{array}$ & $\begin{array}{l}\text { This ratio measures the amount of net income earned with each } \\
\text { sale value generated, calculated by comparing the net income } \\
\text { with the net sales of a firm }\end{array}$ & $\mathrm{NPM}=\frac{\text { NetIncome }}{\text { Sales }} \times 100 \%$ & Ratio \\
\hline $\begin{array}{l}\text { Total Assets } \\
\text { Turn Over } \\
\text { (TATO) }\end{array}$ & $\begin{array}{l}\text { The ratio is used to measure the extent to which the } \\
\text { effectiveness of the firm in using resources in the form of assets } \\
\text { is calculated by dividing sales by total assets. }\end{array}$ & TATO $=\frac{\text { Sales }}{\text { TotalAssets }} \times 100 \%$ & Ratio \\
\hline $\begin{array}{l}\text { Finance } \\
\text { Leverage } \\
\text { Multiplier } \\
\text { (FLM) }\end{array}$ & $\begin{array}{l}\text { An indirect analysis of the use of corporate debt to finance the } \\
\text { total assets owned by the firm, explains the value of all assets } \\
\text { compared to the value of the firm's equity, which is calculated } \\
\text { by comparing the total assets with the total equity held }\end{array}$ & $\mathrm{FLM}=\frac{\text { TotalAssets }}{\text { Equity }} \times 100$ & Ratio \\
\hline Variable & Operational Definition & Proxy & $\begin{array}{l}\text { Measure } \\
\text { Scale }\end{array}$ \\
\hline $\begin{array}{l}\text { Growth Sales } \\
\text { Ratio } \\
\text { (GSR) }\end{array}$ & $\begin{array}{l}\text { Sales growth reflects the successful manifestation of investment } \\
\text { in the past period and can be used as a prediction for the future } \\
\text { growth. Sales growth is also an indicator of a firm's demand and } \\
\text { competitiveness in an industry }\end{array}$ & GSR $=\frac{\text { Sales } \mathrm{t}-\text { Sales } \mathrm{t}-1}{\text { Sales } \mathrm{t}-1} \times 100 \%$ & Ratio \\
\hline $\begin{array}{l}\text { Return on Equity } \\
\text { (ROE) }\end{array}$ & $\begin{array}{l}\text { The profitability ratio is the ability of a firm to operate in the } \\
\text { long run depending on obtaining an adequate level of profit }\end{array}$ & $\mathrm{ROE}=\frac{\text { Net } \operatorname{Pr} \text { ofit }}{\text { Equity }} \times 100 \%$ & Ratio \\
\hline $\begin{array}{l}\text { Price Earnings } \\
\text { Ratio (PER) }\end{array}$ & $\begin{array}{l}\text { Value of firm is the actual value per share that will be received } \\
\text { if the firm's assets are sold at the share price. }\end{array}$ & $\mathrm{PER}=\frac{\text { Market } \operatorname{Pr} \text { icePerShare }}{\text { EarningPerShare }} \times 100 \%$ & Ratio \\
\hline $\begin{array}{l}\text { Types of } \\
\text { Industry }\end{array}$ & $\begin{array}{l}\text { Dummy variables, manufacturing and non-manufacturing } \\
\text { industry }\end{array}$ & $\begin{array}{l}\text { Type of manufacturing industry is assigned a value of "1" } \\
\text { and non-manufacturing industries are assigned a value of } \\
\text { " } 0 \text { " }\end{array}$ & Nominal \\
\hline
\end{tabular}

\section{Results}

The panel data regression methods used in this research was based on the three models, they are: Ordinary Least Square (OLS), Fixed Effect (FE) and Random Effect (RE). The pair test results on the three models can be seen in the Table 2 below: 
Table 2

Model Estimation Test Results

\begin{tabular}{|c|c|c|c|c|}
\hline \multirow{2}{*}{ Effect Test } & \multirow{2}{*}{ Prob $>$ F } & \multicolumn{3}{|c|}{ Best Model } \\
\hline & & Determining test & $($ Prob $>$ F $) /($ Prob $>$ Chibar2 $) /($ Prob $>$ Chi2 $)$ & Description \\
\hline $\begin{array}{l}\text { Ordinary Least Square } \\
\text { (OLS) }\end{array}$ & 0,0000 & $\begin{array}{l}\text { Chow test } \\
\text { (OLS vs FE) }\end{array}$ & 0,0000 & Fixed Effect \\
\hline Random Effect (RE) & 0,0000 & $\begin{array}{c}\text { LM test } \\
\text { (OLS vs RE) }\end{array}$ & 0,0000 & $\begin{array}{l}\text { Random } \\
\text { Effect }\end{array}$ \\
\hline Fixed Effect (FE) & 0,0000 & $\begin{array}{l}\text { Hausman test } \\
\text { (FE vs RE) }\end{array}$ & 0,0000 & Fixed Effect \\
\hline
\end{tabular}

Table 2 above has been proven from the best estimation model test result showing that the Fixed Effect model is the best model with the probability of $0,0000<0,05$ in Chow Test and probability of $0.0000<0,05$ in Hausman Test. It can be concluded that the Fixed Effect Model can be used for the next testing that is the interpretation test of regression. But before that, the Fixed Effect model was tested with the Blue Test that can be seen in the Table 3 below.

Table 3

Blue Test Result

\begin{tabular}{|c|c|c|c|}
\hline Blue Test & Multicollinearity & Heteroscedasticity & Autocorrelation \\
\hline Mean VIF & 3.07 & & \\
\hline Prob $>$ Chi2 & & 0.0000 & \\
\hline Prob $>$ F & & & 0.0009 \\
\hline
\end{tabular}

Source: Data Processing Result

The Blue Test result in the Table 3 proves that the chosen Fixed Effect model has been freed from the multicollinearity (low multicollinearity rate). But, in the heteroscedasticity test, it showed the value of $0,0000<0,05$ which meant that it still had the heteroscedasticity problem. The same thing happened for the autocorrelation test with the value of $0,0009<0,05$ which meant that it has the autocorrelation problem. Based on that condition, the GLS-regression test was done to get the best final data model and can be used as the interpretation data of regression results.

Table 4

Best Regression of ROE Determinants Results

\begin{tabular}{lcc}
\hline ROE & Coef. & $\mathbf{P}>|\mathbf{z}|$ \\
\hline $\mathbf{n m}$. & 1.104277 & 0.000 \\
tato & .4040841 & 0.000 \\
flm & .1625282 & 0.000 \\
gsr & -.1767706 & 0.006 \\
cons. & -.5886472 & 0.000 \\
\hline & & Source: Data Processing Result
\end{tabular}

The estimated variable results of net profit margin variable with coefficient value of 1.104277 , total assets turn over variable with coefficient value of 0.4040841 and finance leverage multiplier with coefficient value of 0,1625282 . The three variables have positive and significant effects with the probability of $<0.05$. While the variable of growth sales ratio with coefficient value of -0.1767706 has negative and significant effect toward return on equity with the probability $<0.05$.

Table 5

Best Regression Results of Dummy Variable of Industry Types toward ROE

\begin{tabular}{ccc|c}
\hline Roe & Coef. & $\mathbf{P}>\mid \mathbf{z}$ & 0.012 \\
\hline $\mathbf{d m}$ & .1235786 & 0.000 \\
\hline cons. & .1560836 & Source: Data Processing Result
\end{tabular}

The result of the estimated dummy variable of manufacture with the coefficient value of 0.1235786 has positive and significant effect toward return on equity with the probability $<0.05$.

Table 6

Best Regression Results of Dummy Variable of Industry Types and ROE toward PER

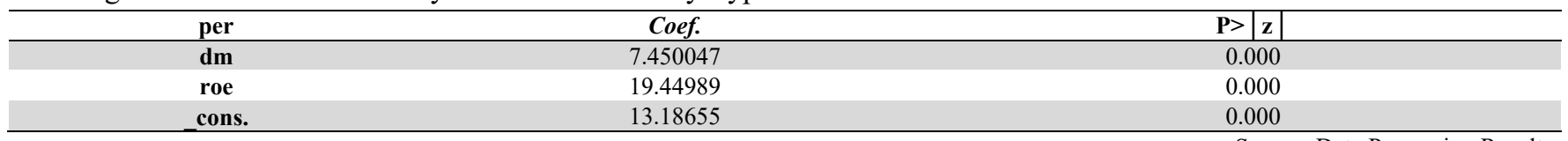


The result of estimated dummy variable of manufacture with the coefficient value of 7.450047 and return on equity variable with coefficient value of 19,44989. Both of the variables have positive and significant effect toward price earnings ratio with the probability $<0.05$.

Table 7

Research's Hypotheses Test Results

\begin{tabular}{|c|c|c|c|c|c|c|}
\hline Нур & Hypothesis Statement & $\begin{array}{l}\text { Coef. } \\
\text { Value }\end{array}$ & Results & $\mathbf{P}>|\mathbf{z}|$ & Sig. & Model \\
\hline $\mathbf{H}_{1}$ & $\begin{array}{l}\text { There is positive effect of } \\
\text { Net Profit Margin on Return } \\
\text { on Equity. }\end{array}$ & 1.104277 & hypothesis accepted & 0.000 & $\sqrt{ }$ & \multirow{3}{*}{$\begin{array}{c}\mathrm{ROE}=-0,5886472+1,104277 * \mathrm{NPM} \\
+0,4040841 * \mathrm{TATO}+ \\
0,1625282 * \mathrm{FLM}-0,1767706 * \mathrm{GSR}\end{array}$} \\
\hline $\mathbf{H}_{2}$ & $\begin{array}{l}\text { There is positive effect of } \\
\text { Total Assets Turn Over on } \\
\text { Return on Equity. }\end{array}$ & 0.4040841 & $\begin{array}{l}\text { hypothesis } \\
\text { accepted }\end{array}$ & 0.000 & $\sqrt{ }$ & \\
\hline $\mathbf{H}_{3}$ & $\begin{array}{l}\text { There is positive effect of } \\
\text { Financial Leverage } \\
\text { Multiplier on Return on } \\
\text { Equity. }\end{array}$ & 0.1625282 & $\begin{array}{l}\text { hypothesis } \\
\text { accepted }\end{array}$ & 0.000 & $\sqrt{ }$ & \\
\hline $\mathbf{H}_{4}$ & $\begin{array}{l}\text { There is positive effect of } \\
\text { Growth Sales Ratio on } \\
\text { Return on Equity. }\end{array}$ & -0.1767706 & Hypothesis denied & 0.006 & - & \multirow[b]{2}{*}{$\begin{array}{c}\text { PER }=13,18655+7,450047 * \mathrm{dm}+ \\
19,44989 * \mathrm{ROE}\end{array}$} \\
\hline $\mathbf{H}_{5}$ & $\begin{array}{l}\text { There is positive effect of } \\
\text { Return on Equity toward } \\
\text { Price Earnings Ratio. }\end{array}$ & 19.44989 & $\begin{array}{l}\text { hypothesis } \\
\text { accepted }\end{array}$ & 0.000 & $\sqrt{ }$ & \\
\hline $\mathbf{H}_{6}$ & $\begin{array}{l}\text { There is positive effect of } \\
\text { manufacture-type industry } \\
\text { toward Return on Equity. }\end{array}$ & 0.1235786 & $\begin{array}{l}\text { hypothesis } \\
\text { accepted }\end{array}$ & 0.012 & $\sqrt{ }$ & \multirow{2}{*}{$\begin{array}{c}\mathrm{ROE}=0,1560836+0,1235786 * \mathrm{dm} \\
\mathrm{PER}=13,18655+7,450047 * \mathrm{dm}+ \\
19,44989 * \mathrm{ROE}\end{array}$} \\
\hline $\mathbf{H}_{7}$ & $\begin{array}{l}\text { There is positive effect of } \\
\text { manufacture-type industry } \\
\text { toward Price Earnings } \\
\text { Ratio. }\end{array}$ & 7.450047 & $\begin{array}{l}\text { hypothesis } \\
\text { accepted }\end{array}$ & 0.000 & $\sqrt{ }$ & \\
\hline
\end{tabular}

\section{Discussion}

\subsection{Net Profit Margin Increasing Return on Equity}

The hypothesis test results stated that the net profit margin has a positive and significant impact toward the return on equity. A high net profit margin value means that the firm is efficient enough in using the finance to fund the firm's operations so that it can increase the sales and generate high net income. A high net profit margin also indicates that the firm is pricing its products correctly and manages to control costs well. This condition in the end can have an impact on the value of return on equity. These results are the same or consistent with research conducted by (Raza, 2017; Warrad \& Nassar, 2017), where both stated that net profit margins have a significant positive effect on return on equity. The investors need to observe how the managements can manage the firms efficiently and look at the future prospect from the profitability, by looking at the percentage of income that used to fund the operational costs, non-operational costs, and dividend share to the shareholders.

\subsection{Total Assets Turn Over Increasing Return on Equity}

In this research, total assets turn over study has a positive and significant effect on return on equity. The value of the total asset turnover is high enough to indicate the firm effectiveness in using the funds invested in assets and managed to the maximum for the operations of the firm to be able to generate production and total sales in a certain amount, to generate operating profit and would lead to return on equity or the rate of return on equity. In other words, to see how many sales will be generated from each rupiah of funds embedded in total assets. Therefore, operational efficiency can be achieved by dividing sales or revenue by total assets, as said by Sari (2007) in (Singapurwoko \& El-Wahid, 2011). The results of this study are the same or consistent with researches conducted by (Bunea et al., 2019; Alarussi \& Alhaderi, 2018; Raza, 2017; Warrad \& Nassar, 2017) where assets turnover indicators have the strongest and most relevant positive influence significantly in determining ROE. However, this result is different from the research conducted by Circiumaru et al. (2010), also Rahmah et.al (2016) \& Jumahana (2017) in 
(Irman \& Purwati, 2020) stated that assets turnover has no linear correlation and has negative and significant relation to profitability.

\subsection{Financial Leverage Multiplier increasing Return on Equity}

Financial leverage multiplier has a positive and significant effect toward return on equity. The best way for a firm to increase the profit is by adding more assets for operations and increasing sales to make more profit, by using leverage in the form of debt instruments. The higher risk will be surely owned, but it can be solved or covered by the efficiency and effectiveness in using the debts funding to increase the operating income and the profit of equity ratio. As stated by Ehrhardt \& Brigham (2008) if it can show the ability to expand the return on equity of the shareholders by having more income compared to the debts and its interest that must be paid to the creditor. This way, the investors might be able to see that the profit on equity is resulted from the debts. This is in line with the Trade-off theory where by focusing on the costs analysis and debts benefit can predict that there is an optimal debt point ratio which could help maximizing the profitability and maximizing the firm's value too in the end. However, this result is different from the research conducted by Saleem \& Rehman (2012) in Raza (2017) stated that firms with high leverage generally have lower profitability. Likewise, with the results of research by (Alarussi \& Alhaderi, 2018; Warrad \& Nassar, 2017; Ahmad et al., 2015) stated that leverage has negative and significant relation toward profitability.

\subsection{Growth Sales Ratio is not increasing Return on Equity}

The negative and significant influence is shown by the growth sales ratio toward the return on equity. As the spearhead, without the existence of a good selling system, the firm won't be able to run. More importantly for the manufacturing firms which the operational activities covering the stages from the upstream to downstream for the production process. To prepare a good production process the firm's management should understand the product sales trend from year to year by using the growth sales ratio, also the right sales forecasting is needed. As stated by Barton et al. (1989) that the growth forecasting in the future can refer to the past investment success story reflected by the growth sales rate.

The firms in order to increase the sales should add more assets investment, so the profit gained from sales will be increasing too. This is based on the opinion from Van Horne \& Wachowicz Jr. (2008) stating that the assets should be added if the firm wants to increase the sales, it is related to the growth sales effect toward profitability. With the addition of these assets, the company can also make product innovation so that it can set apart the company's products from other similar companies. Innovation is needed in order to survive and win the fierce competition, so that it is expected to have an impact on increased sales and increased revenue. Net income will be obtained from the income after deducting for the purpose of paying liabilities both interest costs on investment and income tax payments. The recorded profit shows the potential to become cash. The amount of available cash will determine whether it will be used as a return on equity for the shareholders, will be stored or will be reinvested as retained earnings for the next additional capital. These will determine if the increasing net profit gained will affect the increasing of ROE value and vice versa.

The increase of sales will not automatically affect the increasing ROE. The firms can have increasing growth sales ratio but experience decreasing ROE. It is because the firms are not efficient and not effective in using the operational activity costs, where the total assets ratio is increasing while the leverage of other costs is increasing. As a result, the net profit rate is decreasing. On the contrary, a firm could have a decreasing number for sales but have increasing ROE. It could be because the firm is more efficient in using the operational activity costs, where the net profit margin will increase even though the total assets turnover is decreasing and the leverage of other costs is also increasing. So, the result of this research is said to be inconsistent with the empirical results of the hypothesis which states that growth sales ratio has a positive and significant effect on return on equity. The result is also different from (Cowling, 2004) stated that the growth sales and profitability moved in parallel. But it shares the same result with ones conducted by (Sivathaasan et al., 2013; Jang \& Park, 2011) stated that growth sales didn't affect significantly on profitability.

\subsection{Return on Equity Increasing Price Earnings Ratio}

Return on equity has a positive and significant effect on price earnings ratio. The investment guarantee that has been done can be given by the firms maximally by trying to increase the profit for the shareholders by managing owned capital effectively. The markets will give rewards as an assessment to the firms with high price earnings ratio if the firms have a promising investment opportunity. As long as the return on equity ratio is bigger than the rate return expected by the investors, thus the bigger proportional retained profit will increase the price earnings ratio. It is consistent with Value of the Firm theory which 
stated that the shareholders' prosperity should be given the maximum effort to maximize the firm's value by doing the operational activity effectively and efficiently and developing the firms to gain maximum profit for the firm and the shareholders. It will create such high value for the firm. The result of this research is consistent with (Sucuahi \& Cambarihan, 2016) stated that profitability showed positive and significant influence toward the firm's value.

\subsection{Manufacture-Type Industry Affecting Return on Equity and Price Earnings Ratio}

The manufacture-type industry has positive and significant influence both on return on equity and price earnings ratio. This is due to the characteristics of the manufacturing sector industry which is more complex than the non-manufacturing sector industry, as well as they having different characteristics and functions. These differences lead to different adoption or use of strategies in managing the firm. These results are consistent with the research conducted by Goddard et al. (2005) which proved that the profitability of manufacturing firms was stronger than that of service firms. Also from Mursalim et al. (2015) showing that the type of manufacturing firm positively and significantly affects the firm's profitability and value. As we know, the Indonesian Government through the Industrial Ministry applies the going downstream methods that makes the manufacturing industries growing and has better productivity and gives wider chained effect. To maintain the manufacturing industry values, it needs the support of growing investment and upgrading export performance (KNIC, 2019). With the government policy support, it will attract the investors' interest for investment because the manufacturing industry development prospect is very promising in the future. This is very related to the Value of the Firm theory as stated by Brigham \& Houston (2019) saying that to maximize the shareholders' prosperity is the way to maximize the value of a firm in the long term as the main purpose of the go-public firms.

\section{Conclusions and Research's Limitations}

The research's result showed that net profit margin had a positive and significant effect on return on equity. The positive and significant results were also shown by total assets turn over and financial leverage multiplier variables toward return on equity, and also shown in the relation between return on equity variable toward price earnings ratio. As for the manufacturing sector, industry type had positive and significant effect both toward return on equity and price earnings ratio. While the result that didn't support one of the hypotheses in this research is that the growth sales ratio has negative and significant influence on return on equity.

This research gives limitations for only used annual data from 20 Non-Banking and Financial firms as listed on the IDX, covering a five-year period from 2014 - 2018 and is classified to manufacturing and non-manufacturing firms. The variables used that affect the price earnings ratio is only return on equity variable. Meanwhile, ROE determinants only used indicators from four variables, they are net profit margin, total assets turnover, financial leverage multiplier and growth sales ratio. For the upcoming research, it is expected that it can expand the research object by taking more samples, adding more years of observation or by using different methods and analysis tools, different types of industry, so that research results will be better due to the higher percentage of data representation and adding fundamental variables that can affect both return on equity and price earnings ratio.

\subsection{Managerial Implications}

This research has tried to give a perspective of managerial implication. The high profit before tax could cause a high margin of net profit too. Vice versa, the firms' management should be able to manage the financial resources to maximize the firms' operational. The firms' management need to evaluate to see the assets turnover if the firms' operational activities have been done effectively and efficiently. The firms with high leverage ratio have a big opportunity to make high profit, and it will also affect the firms to have a bigger financial risk. The arousal of financial risk can be anticipated if the firms gain bigger income than the debts compared to the interests that must be paid to the creditor, the surplus will enlarge the ROE for the shareholders of the firms. Or, if the debts are used efficiently and effectively to buy some specified productive assets or to fund the firms' business expansion, or to create innovation in the products, it will create a bigger opportunity for a firm to increase the profitability. The firms' managements need to make an effort in order to increase the sales that are accompanied by the higher net profit by covering the operational costs for production activity using the sales to increase the profit. Besides, the firms' management need to always calculate the policy of net profit gained whether they will be allocated for ROE distribution to the shareholders or to be saved as retained profit as additional owned capital. However, the investors' or the shareholders' satisfaction will increase the trust and influence the perceptions of the investors or the other investors candidate toward the firms' success rate that often linked with the stock price and affect the assessment in the value of firm where the markets not only believe in the current firms' performance but also their prospects in the future. These perceptions will help the investor candidates in making decisions for investment. 
Ahmad, N., Salman, A., \& Shamsi, A. F. (2015). Impact of Financial Leverage on Firms ' Profitability : An Investigation from Cement Sector of Pakistan. Research Journal Of Finance And Accounting, 6(7), 75-81.

Alarussi, A. S., \& Alhaderi, S. M. (2018). Factors affecting profitability in Malaysia. Journal of Economic Studies, $45(3), 442-458$. https://doi.org/10.1108/JES-05-2017-0124

Barton, S. L., Hill, N. C., \& Sundaram, S. (1989). An Empirical Test of Stakeholder Theory Predictions of Capital Structure. Financial Management "Wiley”, Financial Management Association International, 18(1), 36-44.

Brigham, E. F., \& Houston, J. F. (2009). FUNDAMENTALS OF FINANCIAL MANAGEMENT Concise Sixth Edition. In J. W. Calhoun (Ed.), South-Western CENGAGE Learning (6th ed.). South-Western CENGAGE Learning.

Brigham, E. F., \& Houston, J. F. (2019). Fundamentals of financial management. In A. von Rosenberg (Ed.), Fundamentals of financial management (12th $\quad$ ed.). South-Western $\quad$ CENGAGE https://doi.org/10.12737/textbook_5d3961a55db7f9.62246330

Bunea, O. I., Corbos, R. A., \& Popescu, R. I. (2019). Influence of some financial indicators on return on equity ratio in the Romanian energy sector - A competitive approach using a DuPont-based analysis. Energy, $189,116251$. https://doi.org/10.1016/j.energy.2019.116251

Circiumaru, D., Siminica, M., \& Marcu, N. (2010). a Study on the Return on Equity for the Romanian Industrial Companies. Annals of University of Craiova - Economic Sciences Series, 2(38).

Cowling, M. (2004). The growth - Profit nexus. Small Business Economics, 22(1), 1-9. https://doi.org/10.1023/B:SBEJ.0000011568.42714.c9

Ehrhardt, M. C., \& Brigham, E. F. (2008). Financial Management: Theory and Practice. In Financial Management: Theory and Practice (13th ed.). South-Western CENGAGE Learning. https://doi.org/10.1002/9781119057093.app4

Gitman, L. J., \& Zutter, C. J. (2015). Principles of Managerial Finance. In Donna Baltista (Ed.), Prentice Hall, PEARSON (13th ed.). Prentice Hall, PEARSON. https://doi.org/10.2307/2977800

Goddard, J., Tavakoli, M., \& Wilson, J. O. S. (2005). Determinants of profitability in European manufacturing and services: Evidence from a dynamic panel model. Applied Financial Economics, 15(18), 1269-1282. https://doi.org/10.1080/09603100500387139

Irman, M., \& Purwati, A. A. (2020). Analysis On The Influence Of Current Ratio, Debt to Equity Ratio and Total Asset Turnover Toward Return On Assets On The Otomotive and Component Company That Has Been Registered In Indonesia Stock Exchange Within 2011-2017. International Journal of Economics Development Research (IJEDR), 1(1), 36-44. https://doi.org/10.37385/ijedr.v1i1.26

Jang, S. C. (Shawn), \& Park, K. (2011). Inter-relationship between firm growth and profitability. International Journal of Hospitality Management, 30(4), 1027-1035. https://doi.org/10.1016/j.ijhm.2011.03.009

Karimah, U. (2018). Analisis Pengaruh Current Ratio, Debt To Equity Ratio, Total Assets Turnover, Net Profit Margin Terhadap Return on Equity Pada Perusahaan Manufaktur Di Bursa Efek Indonesia Periode 2008-2010. Manajerial, 1(1), 14. https://doi.org/10.30587/manajerial.v1i1.424

Kijewska, A. (2016). Determinants of the return on equity ratio (ROE) on the example of companies from metallurgy and mining sector in Poland. Metalurgija, 55(2), 285-288.

KNIC. (2019). Perkembangan Industri Manufaktur Indonesia. KARAWANG New Industry City.

Lestari, S. A., \& Armayah, M. (2016). Profitability and Company Value: Empirical Study of Manufacture Companies in Indonesia Period 2009 - 2014. Information Management and Business Review, 8(3), 6-10. https://doi.org/10.1017/CBO9781107415324.004

Mursalim, Hendragunawan, Alamzah, N., \& Sanusi, A. (2015). Financial Decision, Innovation, Profitability and Company Value: Study on Manufacturing Company Listed in Indonesian Stock Exchange. Information Management and Business Review, 7(2), 72-78. https://doi.org/10.22610/imbr.v7i2.1141

Myers, S. C. (2001). Capital Structure. Journal of Economic Perspectives, 15(2), 81-102. https://doi.org/10.1017/9781316105795.005

Pervan, M., Pervan, I., \& Ćurak, M. (2019). Determinants of firm profitability in the Croatian manufacturing industry: evidence from dynamic panel analysis. Economic Research-Ekonomska Istrazivanja, 32(1), 968-981. https://doi.org/10.1080/1331677X.2019.1583587

Raza, A. (2017). Determinants of Return on Equity: Evidence from the Cement Industry of Pakistan. KASBIT Business Journal, 10(Special Issue), 106-119.

Singapurwoko, A., \& El-Wahid, M. S. M. (2011). The impact of financial leverage to profitability study of non-financial companies listed in Indonesia stock exchange. European Journal of Economics, Finance and Administrative Sciences, 32, $136-148$.

Sivathaasan, N., Tharanika, R., Sinthuja, M., \& Hanitha, V. (2013). Factors Determining Profitability: A Study of Selected Manufacturing Companies Listed on Colombo Stock Exchange in Sri Lanka. European Journal of Business and Management, 5(27), 99-108.

Sucuahi, W., \& Cambarihan, J. M. (2016). Influence of Profitability to the Firm Value of Diversified Companies in the Philippines. 
Accounting and Finance Research, 5(2). https://doi.org/10.5430/afr.v5n2p149

Suwardi, A. (2011). MODUL STATA : Tahapan Dan Perintah (Syntax) Vector Autoregressivee (VAR) (2011). Scribd Website.

Van Horne, J. C., \& Wachowicz Jr., J. M. (2008). Financial management. In Workplace Strategies and Facilities Management. https://doi.org/10.4324/9780080521299

Warrad, L. H., \& Nassar, M. (2017). Could Profitability, Activity and Use of Equity Finance Increasing DuPont Model of Return on Equity? Jordanian Case. International Review of Management and Marketing, 7(3), 35-41.

Weidman, S. M., McFarland, D. J., Meric, G., \& Meric, I. (2019). Determinants of return-on-equity in USA, German and Japanese manufacturing firms. Managerial Finance, 45(3), 445-451. https://doi.org/10.1108/MF-07-2018-0305

Winarto, J. (2015). The Determinants of Manufacturer Firm Value in Indonesia Stock Exchange. International Journal of Information, Business and Management, 7(4), 323-349. https://doi.org/10.1016/j.ijinfomgt.2010.11.002

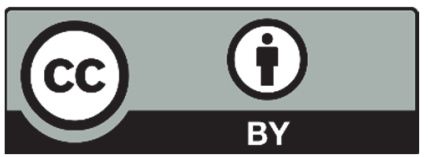

(C) 2021 by the authors; licensee Growing Science, Canada. This is an open access article distributed under the terms and conditions of the Creative Commons Attribution (CC-BY) license (http://creativecommons.org/licenses/by/4.0/). 